\author{
dr Aneta KARGOL-WASILUK \\ Wydział Ekonomii i Zarządzania, Uniwersytet w Białymstoku \\ e-mail: a.kargol@uwb.edu.pl \\ mgr Ewa WOJEWÓDKO \\ Wydział Finansów i Budżetu, Podlaski Urząd Wojewódzki \\ e-mail: ewojewodko@bialystok.uw.gov.pl
}

DOI: $10.15290 /$ ose.2017.02.86.11

\title{
BUDŻET ZADANIOWY JAKO NARZĘDZIE POPRAWY JAKOŚCI RZĄDZENIA (NA PRZYKłADZIE PODLASKIEGO URZĘDU WOJEWÓDZKIEGO)
}

\begin{abstract}
Streszczenie
Artykuł został poświęcony analizie efektów funkcjonowania budżetu zadaniowego w Polsce na przykładzie urzędu wojewódzkiego. Skupiono się w nim na możliwości wykorzystania budżetu zadaniowego jako instrumentu poprawy jakości rządzenia ze względu na takie wymiary, jak: demokratyczne państwo prawne, przejrzystość, rozliczalność, efektywność i skuteczność, partycypacja oraz inkluzja społeczna. W artykule poruszono problem zalet i wad budżetu zadaniowego. Uzyskane wyniki pozwoliły na sformułowanie wniosku o wykorzystywaniu budżetu zadaniowego w Polsce jako narzędzia prezentacyjnego, a tylko w umiarkowanym stopniu jako instrumentu zwiększającego efektywność i skuteczność wydatkowania środków publicznych. Natomiast osiagnięcie lepszych efektów jego stosowania będzie możliwe, jeśli zostanie on powiązany z kontrolą zarządczą. Pod względem poprawy jakości rządzenia obecnie budżet zadaniowy spełnia kryterium demokratycznego państwa prawnego i kryterium przejrzystości. Kolejne wymiary dobrego rzadzenia będą mogły być osiagane, gdy budżetowanie zadaniowe zostanie wprowadzone jako obligatoryjne narzędzie we wszystkich jednostkach sektora finansów publicznych, co spowoduje większą dbałość o realizację celów określonych w jego ramach.
\end{abstract}

Słowa kluczowe: jakość rządzenia, budżet zadaniowy, wymiary dobrego rządzenia, urząd wojewódzki

\section{IMPROVING QUALITY OF PUBLIC GOVERNANCE THROUGH PERFORMANCE BUDGET: THE CASE OF PODLASKIE PROVINCE OFFICE}

\section{Summary}

The paper analyses the effects of the implementation of performance budgeting in Poland, as exemplified by the province governor's office. The author focuses on the possibility of applying the performance budget as an instrument for improving public governance in terms of: democratic rule of law, transparency, accountability, efficiency and effectiveness, participation and social inclusion. The paper also discusses the advantages and disadvantages of performance budgeting. The obtained results lead to the conclusion that performance budgeting in Poland is used as a tool for presentation, and only to a small degree as an instru- 
ment for increasing the efficiency and effectiveness of public spending. Greater benefits from performance budgeting will be achieved, if its implementation is associated with management control. As far as improving public governance is concerned, performance budgeting in Poland meets the criteria of the democratic rule of law and transparency. Other dimensions of good governance can be reached through performance budgeting when it is introduced as an obligatory tool in every public entity, which will result in greater attentiveness to the realisation of its objectives.

Key words: public governance, performance budget, dimensions of good governance

JEL: H6, H61, H11

\section{Wstęp}

Współcześnie sposób funkcjonowania sektora publicznego ma niezaprzeczalnie istotny wpływ na jakość życia obywateli. Stąd istnieje potrzeba ciagłej poprawy jakości rządzenia (ang. public governance), które powinno służyć całemu społeczeństwu. Rządzenie ma wiele wymiarów, a jego skuteczność i efektywność, które składają się na pożądana jakość, zależą od wielu czynników. Obecnie prowadzi się coraz więcej badań nad jakością rządzenia, odrębnie analizując jego poszczególne wymiary. Wśród powszechnie uznanych wymiarów tzw. dobrego rządzenia (ang. good governance) wymienia się takie aspekty, jak: demokratyczne państwo prawne, przejrzystość, rozliczalność, skuteczność i efektywność, partycypacja oraz inkluzja społeczna. Poszczególne wymiary są ze soba powiązane, mogą wzajemnie wzmacniać się i na siebie oddziaływać. Biorąc pod uwagę ideę dobrego rządzenia, w sferze finansów publicznych istotnego znaczenia nabiera koncepcja budżetu zadaniowego, który jako narzędzie sprawnego zarzadzania środkami publicznymi może być postrzegany jako instrument poprawy jakości rządzenia. W odniesieniu do efektów ekonomicznych i społecznych budżetowanie zadaniowe stanowi metodę budżetowania wykorzystująca informację o wynikach realizacji zadań publicznych. W wąskim ujęciu budżet zadaniowy ma służyć odpowiedzi na pytanie: w jaki sposób zrealizować określone wydatki? Natomiast w szerokim ujęciu polega na planowaniu wydatków z uwzględnieniem możliwości poprawy osiaganych wyników (co i dlaczego chcemy osiągnąć́?).

Celem artykułu jest zbadanie możliwości wykorzystywania budżetu zadaniowego do poprawy jakości rządzenia w jednostkach sektora finansów publicznych w Polsce na przykładzie Podlaskiego Urzędu Wojewódzkiego (w ramach wybranego działania). Zasadniczym problemem jest bowiem racjonalność wydatkowania środków publicznych, która znacząco wpływa na jakość rządzenia. Do badań empirycznych wybrano podmiot, w którym jedna $z$ autorek pracuje na stanowisku bezpośrednio związanym m.in. $z$ nadzorowaniem wdrażania budżetu zadaniowego. W zamyśle była leży próba skonfrontowania wiedzy teoretycznej z praktycznymi aspektami jego stosowania w badanej jednostce.

W opracowaniu wykorzystano metodę deskryptywną z elementami analizy konkretnego przykładu zastosowania budżetu zadaniowego. Wybór przedmiotowego podejścia badawczego znajduje uzasadnienie ze względu na ograniczone możliwości prezen- 
tacyjne budżetu zadaniowego w całości (w ramach: wszystkich funkcji państwa, zadań, podzadań oraz celów i mierników).

\section{Teoretyczne aspekty jakości rządzenia}

Analizując problem jakości rządzenia, warto rozpocząć rozważania od wyjaśnienia istoty pojęcia governance. Termin ten jest stosunkowo mocno zakorzeniony w debacie akademickiej oraz retoryce politycznej, co nie oznacza utrzymania jego koncepcyjnej dokładności [Monteduro, Hinna, Gnan, 2013, s. 3]. Pojęcie governance, mimo licznych prób, nie doczekało się, jak dotychczas, ujednoliconej definicji. Stosuje się także różne sposoby jego tłumaczenia. W języku polskim tę kategorię tłumaczy się jako: rządzenie, sprawowanie władzy, współrządzenie, współzarządzanie, ład, koordynacja, a nawet zarządzanie. Ogólne znaczenie terminu governance: (...) odnosi sie do wssystkich woorców regut. Jest to ₹biór zasad prayjetych przez organizacje taka jak: przedsiebiorstwo lub państwo, określajacych, jak rzadzic i jakie zasady stosować w relacjach wewnetrzyych $i$ zewnetrzmych miedsy interesariuszami [Valkama, Bailey, Anttiroiko, 2011, s. 3]. Governance jest pojęciem z gruntu nauk ekonomicznych oraz nauk politologicznych, a nawet socjologicznych. Jak stwierdza B. Jessop, łatwo je przenosić pomiędzy granicami różnych szkół myślenia i dyscyplin naukowych oraz różnymi obszarami praktycznego zastosowania [Jessop, 2007, s. 5]. Obecnie governance jest dość szeroko rozpowszechnione i przedstawiane w różnych kontekstach. Można bowiem mówić o: ładzie korporacyjnym (corporate governance), globalnym współrządzeniu (global governance), współzarządzaniu miastem (urban governance), zarządzaniu Internetem (Internet governance), europejskiej koordynacji gospodarczej (European economic governance), współzarządzaniu środowiskiem (environmental governance) itp. [Hill, Lynn, 2004, s. 4].

Pierwotnie kategoria governance była obszarem badań na gruncie sektora prywatnego (governance structures), choć samo governing, to govern zawsze było zarezerwowane dla sfery, w której działają rząd i inne podmioty sfery publicznej. Jak zauważa J. Wilkin, problematyka badawcza w tym obszarze została spopularyzowana począwszy od lat siedemdziesiątych i osiemdziesiatych XX wieku przez przedstawicieli nowej ekonomii instytucjonalnej (NEI), szczególnie przez O. E. Williamsona [Jakość rz̨adżenia w Polsce..., 2013, s. 20]. Ten czołowy reprezentant NEI analizował governance structures w sferze działalności gospodarczej i podmiotów rynkowych, takich jak wielkie korporacje. $\mathrm{Na}$ przełomie lat osiemdziesiątych i dziewięćdziesiatych XX wieku zaczęto używać pojęcia governance na gruncie sektora publicznego, do czego znacząco przyczynił się Bank Światowy. Zgodnie z definicją Banku Światowego, governance oznacza: uykerzysstywanie politycznej wtadsy i sprawowanie kontroli w obrebie spoleczenśntwa, w powiqzaniu z zarz̨adzaniem jego zasobami na rzecz. spotecznego i gospodarczego rozwoju [Orientations on Participatory Development..., 1993, s. 7]. Ta szeroka definicja obejmuje rolę władz publicznych w ustanawianiu środowiska, w którym funkcjonuja podmioty gospodarcze i określaniu sposobu podziału korzyści oraz naturę relacji między rządzącymi a rządzonymi.

Od początku lat dziewięćdziesiątych XX wieku obserwuje się zainteresowanie idea public governance (jakość rządzenia, publiczne rządzenie, współzarządzanie, rządzenie 
partycypacyjne, administracja partnerska) [por. Public governance, 2015] jako obszarem intensywnej eksploracji, ukształtowanym na fali rozczarowania skutecznościa programów pomocowych kierowanych do krajów rozwijających się przez Bank Światowy i Międzynarodowy Fundusz Walutowy [Grosse, 2009, s. 113]. Jak zauważa T. Grosse, nieskuteczność tychże programów ujawniła zależność między efektywnym wykorzystywaniem pomocy a potencjałem administracji publicznej, która odpowiada za realizację programów [Grosse, 2009]. Wraz z procesami deregulacji gospodarki światowej w XX wieku (lata osiemdziesiąte i dziewięćdziesiąte) w wielu krajach pojawiły się nowe koncepcje funkcjonowania państwa i sfery publicznej (w tym organizacji sektora finansów publicznych). W takich państwach, jak: Wielka Brytania, USA, Australia, Nowa Zelandia rozpoczął się proces intensywnych reform, zmierzających do usprawnienia ich działania, a wkrótce rozprzestrzenił się na inne kraje, w tym z bloku postsocjalistycznego.

W opracowaniu OECD z 1993 roku wyróżniono trzy znaczenia governance w odniesieniu do sfery publicznej. O public governance można zatem mówić jako: 1) formie politycznego reżimu (sposób organizacji działania państwa); 2) procesie, za pośrednictwem którego sprawuje się władzę w zakresie zarządzania ekonomicznymi i społecznymi zasobami (pewien model zarządzania); 3) zdolności rządu do formułowania i wdrażania polityk i realizowania funkcji rządu (skuteczność i efektywność funkcjonowania państwa) [por. Kargol-Wasiluk, 2011]. Do charakterystycznych cech public governance należą:

- dominacja sieci - dominacja nieformalnych instytucji, ale amorficznego zbioru aktorów, wpływających na to, w jaki sposób oraz jakie dobra publiczne i usługi będą dostarczane;

- malejąca zdolność państwa do sprawowania bezpośredniej kontroli;

- $\quad$ łączenie zasobów publicznych i prywatnych;

- $\quad$ korzystanie z różnorodnych instrumentów [por. Kargol-Wasiluk, 2011].

W ogólnym sensie public governance oznacza zdolność rządu do funkcjonowania razem lub bez sektora prywatnego, w celu kierowania gospodarką i społeczeństwem na rzecz osiagania wspólnych celów [Peters, 2012]. Jak zauważa B.G. Peters, public governance może być realizowane dzięki wykorzystaniu tradycyjnych metod o charakterze hierarchicznym, co wiąże się z tym, że fundamenty takiego współrządzenia wyrastają z koncepcji tradycyjnych rządów (scentralizowanych i autokratycznych). Współcześnie ma to miejsce $\mathrm{w}$ wielu krajach. Tradycyjne metody wykorzystuje się np. w sferze opodatkowania, regulacji działalności gospodarczej itp. - nawet w państwach, w których istnieją silne tendencje do rządzenia przy wykorzystaniu bardziej interaktywnych mechanizmów. Dzieje się tak, ponieważ dany model governance może być nieodpowiedni dla każdego systemu politycznego bądź polityki publicznej. Przywoływany autor zauważa, że termin governance stał się popularny częściowo dlatego, że stanowi alternatywę dla tradycyjnych, hierarchicznych form rządzenia państwem narodowym, zwłaszcza w scentralizowanych systemach. Główną logiką rządzenia bez rządu jest to, że samoorganizujące się sieci aktorów moga zapewnić alternatywne, bardziej efektywne, demokratyczne wzorce rządzenia [Peters, 2012]. Z kolei F. Fukuyama w swoich rozważaniach wiele uwagi poświęca badaniu funkcjonowania władzy pub- 
licznej, analizując cechy dobrego i złego rządu, czy też poszukując odpowiedzi na pytanie o miary i czynniki jakości rządzenia [Fukuyama, 2014]. W odniesieniu do sektora publicznego zjawisko governance definiuje jako zdolność do tworzenia i egzekwowania prawa oraz do dostarczania dóbr i usług publicznych, niezależnie od tego, czy rząd jest demokratyczny, czy nie [Fukuyama, 2013, s. 347 i nast.]. W swoich badaniach zauważa, że do pomiaru jakości rządzenia badacze podchodza patrząc przez pryzmat czterech miar, takich jak: 1) miary proceduralne, tj. weberowskie kryteria biurokratycznej nowoczesności; 2) miary zdolności (pojemności), które obejmuja zarówno zasoby, jak i stopień profesjonalizacji administracji publicznej i sektora publicznego; 3) miary wyników; 4) miary biurokratycznej autonomii. W zasadzie Fukuyama odrzuca miary wyników i proponuje dwuwymiarowe ramy badania - zdolność (pojemność) administracji publicznej oraz jakość egzekutywy [Fukuyama, 2013].

$\mathrm{Na}$ podstawie dotychczasowej analizy można stwierdzić, że public governance stanowi teoretyczny paradygmat instytucjonalny koordynacji działań zbiorowych (funkcjonowania państwa i sfery publicznej) [por. Jessop, 2007]. Jest to o tyle ważne, że w obszarze gospodarki finansami publicznymi kluczowe wydaje się pytanie o zdolność do racjonalizacji wydatków publicznych, co nie jest możliwe bez skutecznej koordynacji, a więc formułowania i wdrażania polityk rządu. W kontekście prowadzonych rozważań powstaje zatem pytanie o to, czym jest dobre rządzenie (good governance). Rotberg uważa, że wspótrz̨adzenie jest dobre, gdy powoduje takie rozdysponowanie i zarządzanie zasobami, które odpowiada potrzebom zbiorowym, innymi słowy, gdy rząd efektywnie dostarcza dobra publiczne o odpowiedniej jakości. Stąd rządy powinny być oceniane zarówno pod kątem jakości, jak i ilości dostarczanych dóbr [Rotberg, 2004, s. 71-81]. Dostarczanie dóbr publicznych w ramach polityk publicznych opiera się na takich zasadach, jak: przestrzeganie praw czlowieka, demokratyzacja i demokracja, przejrzystość, partycypacja, udział zdecentralizowanej władzy, dobra administracja publiczna, odpowiedzialność i rozliczalność, praworządność, skuteczność, równość, strategiczna wizja [Cheema, 2005, s. 4-5]. Good governance umożliwia ograniczenie, ewentualnie pozbycie się, korupcji. Promuje równość płci, pozytywnie wpływa na zrównoważony rozwój, pozwala obywatelom na korzystanie z wolności osobistych, dostarcza narzędzi do walki z: ubóstwem, niedostatkiem, strachem i przemocą. Organizacja Narodów Zjednoczonych postrzega good governance jako partycypacyjny, transparentny i rozliczalny system. Obejmuje on instytucje państwa i ich działania, a także sektor prywatny oraz organizacje społeczeństwa obywatelskiego. W praktyce takie zasady powinny przełożyć się na „wzmocnienie instytucji demokratycznych” [Cheema, 2005].

W polskiej literaturze analizuje się wymiary dobrego rządzenia, ujęte jako katalog otwarty. Liczni autorzy badaja jakość rządzenia przez pryzmat takich wymiarów, jak: demokratyczne państwo prawne, przejrzystość (transparentność), efektywność i skuteczność, rozliczalność, partycypacja, inkluzja społeczna. Każdy z tych wymiarów jest ważny i umożliwia dokonanie oceny procesu rządzenia, chociaż powinno się je raczej rozpatrywać jako wymiary współwystępujące i wzajemnie na siebie oddziałujące. Powołując się na L. Hardta i M. de Jonga, można zdefiniować te wymiary następująco: 1) demokratyczne państwo prawne - jako gwarancja adaptacyjnej efektywności pań- 
stwa, dotyczy budowy instytucji demokratycznych umożliwiajacych obywatelom wpływ na sprawy publiczne; 2) przejrzystość - oznacza: jawne i transparentne sprawowanie władzy, dostępność do informacji publicznej, w tym przez Internet, czytelność informacji publicznej, przejrzysty proces stanowienia prawa, monitorowanie postępów; 3) rozliczalność - wiąże się z opracowaniem mechanizmów i procedur rozliczalności władz publicznych z realizacji wcześniej przyjętych założeń programów wykonawczych i obietnic składanych społeczeństwu; wiążę się z obecnością mechanizmów, które czynią urzędników odpowiedzialnymi za ich decyzje; 4) efektywność i skuteczność - istnienie jasno określonych celów i dążenie do ich realizacji w sposób oszczędny; lepsze zarządzanie jednostkami sektora publicznego; zapewnienie adekwatności osiaganych efektów polityki publicznej do identyfikowanych potrzeb społecznych, właściwe wyznaczanie celów oraz dobór metod i narzędzi ich osiagania; ekonomiczność wyrażająca się w relacjach jakości do ceny oferowanych usług publicznych czy racjonalna gospodarka finansowa; 5) partycypacja - obywatele biorą udział w procesie podejmowania decyzji; 6) społeczna inkluzja - jednostki, grupy bądź poszczególne kategorie społeczne są włączane w funkcjonowanie społeczeństwa [por. Hardt, de Jong, 2011, s. 10]. Wyodrębnione wymiary dobrego rządzenia mogą stanowić odpowiedni punkt odniesienia do analizy procesu wdrażania budżetu zadaniowego.

\section{Istota budżetu zadaniowego}

Korzenie budżetowania zadaniowego sięgają tradycji anglosaskiej. Mianem budżetu zadaniowego często określa się nowy model zarządzania finansami publicznymi. Budżetowanie zadaniowe, według koncepcji przyjętej przez OECD, jest takim modelem budżetowania, który polega na łączeniu wydatków z wymiernymi rezultatami. W ogólnym ujęciu przez budżetowanie rozumie się proces przekształcania informacji w decyzję [Schick, 2007, s. 110]. Jak zauważa uznany autorytet w zakresie budżetowania zadaniowego, A. Schick, historia budżetowania jest w istocie historią reform sektora publicznego, sięgającą końca lat czterdziestych XX wieku. Pojawiła się wówczas jako kluczowa siła napędowa budżetowej innowacji w USA. Przywoływany autor uważa, że łatwo wyjaśnić, na czym polega budżetowanie zadaniowe, ale trudno je wdrożyć [Schick, 2007, s. 122]. Podstawowym założeniem jest to, że rządy powinny preliminować (budżetować) rzeczywiste lub oczekiwane rezultaty, zamiast skupiać się na danych wyjściowych. Kiedy budżet jest opracowywany, rząd powinien być informowany o usługach, które będą dostarczane przez jednostki sektora publicznego oraz o oczekiwanych korzyściach i warunkach społecznych, które będą wynikać z wydatkowania środków publicznych. Jest to jednak niezwykle trudne, chociaż w sensie idei bardzo pożądane. Obecnie nie ma żadnej zunifikowanej definicji budżetu zadaniowego (budżetowania zadaniowego). Na określenie analizowanego zjawiska stosuje się różnorodne nazwy, takie jak: budżet zadaniowy, budżet wyników i np. performance funding. Generalną zasadą jest ujęcie w procesie budżetowym oczekiwanych rezultatów [Performance Budgeting in OECD Countries, 2007, s. 20-22]. W ramach OECD wyróżnia się różne kategorie budżetu zadaniowego oparte na proponowanym zastosowaniu formalnej 
informacji o wynikach powstałych w procesie budżetowym. Pierwszą kategoria jest budżet o charakterze prezentacyjnym, w którym wystarczy, aby informacje o wynikach zostały przedstawione w dokumentach budżetowych lub innych dokumentach rządowych. W ramach tej kategorii informacje o wynikach sa dołączane jako tło informacyjne dla celów odpowiedzialności i dialogu między ustawodawcą a obywatelem w sprawach publicznych oraz kierunku polityki rządowej. Nie występuje tutaj związek między informacja o wynikach a finansowaniem. Informacje te nie odgrywaja roli w podejmowaniu decyzji o alokacji zasobów i nie jest to w tym przypadku celem. Budżet informacyjny, jako druga kategoria, polega na tym, że źródła finansowania sa powiązane zarówno z przyszłymi, jak i osiagniętymi rezultatami w pośredni sposób. Formalne informacje o wynikach wykorzystuje się w celu podania do wiadomości decyzji budżetowych wraz z innymi informacjami związanymi np. z ograniczeniami w skali makro, w zakresie polityki fiskalnej oraz priorytetów polityki publicznej i interesów politycznych. Jednocześnie nie ma automatycznych i mechanicznych powiązań między celami bądź wynikami a źródłami finansowania. Informacje o wynikach są istotne, ale nie bezwzględnie, jak również nie odgrywają predefinicyjnej roli w podejmowaniu decyzji. Ostatecznie zależy to od szczególnego kontekstu politycznego. Budżet decyzyjny, jako trzecia kategoria, oznacza bezpośrednie budżetowanie zadaniowe. Występujące powiązania dotyczą bezpośredniej i wyraźnej alokacji zasobów do jednostek wydatkujących środki publiczne, czyli dotyczą wyników. Stosuje się przy tym specyficzne wskaźniki oceny wydajności. Finansowanie bezpośrednio jest oparte na osiagniętych wynikach. Tę forma budżetowania wykorzystuje się tylko w specyficznych sektorach (np. w edukacji wyższej) i tylko w pewnej grupie krajów. W ramach bezpośredniego budżetowania stosuje się system nagród i kar na podstawie oceny osiaganych rezultatów [Performance Budgeting..., 2007].

W Polsce wdrażanie budżetu zadaniowego rozpoczęto w 2006 roku [por. Postuła, Perczyński, 2008, s. 184]. Podjęto wówczas decyzję wiążącą się z rozpoczęciem prac nad reforma finansów publicznych. W Kancelarii Prezesa Rady Ministrów opracowano pierwszy dokument wprowadzający nowe metody budżetowania i zarządzania budżetem państwa. Określenie nowego sposobu budżetowania zadaniowego znalazło się w dokumentach programowych i strategicznych rządu, takich jak Krajowy Program Reform i Strategia Rozwoju Kraju. W tym samym roku podjęto również działania operacyjne, wprowadzając pierwszy model budżetu zadaniowego państwa w zakresie dwóch części budżetowych: Nauka oraz Szkolnictwo Wyższe. Natomiast przepisy o zadaniowym planie wydatków znalazły się w Ustawie o finansach publicznych $w$ grudniu 2006 roku oraz w Uzasadnieniu do projektu ustany budżetowej na 2007 rok [Ustawa budzetowa na rok 2007. Uzasadnienie...].

Definicję układu zadaniowego zawarto w Ustawie z dnia 27 sierpnia 2009 roku ofinansach publicznych (tekst jednolity: Dz. U. z 2013, poz. 885 z późn. zm.). Zgodnie $z$ art. 2 ust. 3 przedmiotowej ustawy, układ zadaniowy jest zestawieniem odpowiednio: wydatków budżetu państwa lub kosztów jednostki sektora finansów publicznych, sporządzonym według funkcji państwa, oznaczających poszczególne obszary działań państwa, oraz: a) zadań budżetowych grupujących wydatki według celów; b) podzadań budżetowych grupujących działania umożliwiające realizację celów zadania, 
w ramach którego podzadania te zostały wyodrębnione - wraz z opisem celów tych zadań i podzadań, a także z bazowymi i docelowymi miernikami stopnia realizacji celów działalności państwa, oznaczającymi wartościowe, ilościowe albo opisowe określenie bazowego i docelowego poziomu efektów z poniesionych nakładów [Ustawa z dnia 27 sierpnia 2009 roku..., 2013].

W strukturze układu zadaniowego wyróżnia się zatem cztery poziomy. Są to:

- $\quad$ funkcje państwa - stanowią najwyższy szczebel układu zadaniowego. Funkcje o numerach od 1.-21. odnoszą się do poszczególnych obszarów działań państwa. Funkcja 22. - Koordynacja dziatalności oraz obstuga administracyjna i techniczna - ma charakter techniczny;

- $\quad$ zadania - tworzą drugi szczebel klasyfikacji zadaniowej. Przypisuje się do nich środki finansowe przeznaczone na realizację celów funkcji państwa, w ramach której zostały zdefiniowane zadania;

- podzadania - dotyczą trzeciego szczebla klasyfikacji zadaniowej o charakterze operacyjnym. Przypisuje się do nich wydatki służące realizacji celów zadania, w ramach których zostały wyodrębnione;

- działania - tworza najniższy szczebel klasyfikacji zadaniowej. Obejmuja wszystkie najważniejsze elementy procesu osiagania celów podzadania oraz celów szczegółowych zadania [Ustawa z. dnia 27 sierpnia 2009 roku..., 2013].

Do każdego z wymienionych poziomów w strukturze układu zadaniowego określa się cele i mierniki. Na poziomie funkcji, cele i mierniki są definiowane przez ministrów wiodących $w$ ich realizacji. Na poziomie zadań, cele i mierniki są definiowane przez ministrów, organy bądź dysponentów właściwych dla poszczególnych zadań. Na poziomach podzadań i działań, cele i mierniki są ustalane przez dysponentów (np. wojewodów). Dla każdego realizowanego przez siebie podzadania lub działania dysponent definiuje nie więcej niż po trzy cele i trzy mierniki. Formułowania i doboru celów i mierników realizacji podzadań i działań w budżecie zadaniowym wojewody dokonują dyrektorzy wydziałów i kierownicy jednostek. Cele i mierniki służą rzetelnemu pomiarowi i obiektywnej ocenie efektywności lub skuteczności realizacji planów w układzie zadaniowym [Ustawa z dnia 27 sierpnia 2009 roku..., 2013]. Cel odzwierciedla stan, który państwo zamierza osiagnać, wydatkując środki publiczne. Cele powinny być:

- $\quad$ istotne, tj. obejmować najważniejsze obszary działalności, wyrażać istotne potrzeby społeczno-ekonomiczne kraju, postrzegane jako ważne z punktu widzenia społeczeństwa i jednostek je realizujących. Powinny w sposób istotny (skala, zakres czasowy oraz przedmiotowy rezultatu) przyczyniać się do zaspokojenia potrzeb społecznych w zakresie danej polityki państwa;

- precyzyjne i konkretne, tj. odnosić się bezpośrednio do podstawowego, zamierzonego wyniku realizacji zadań i podzadań, sformułowane w sposób jasny i zapewniający ich jednoznaczną interpretację. Należy unikać zbyt szczegółowych, obszernych definicji, technicznych skrótów bez ich objaśnienia. Celem nie powinno być samo działanie realizowane przy użyciu wydatków, lecz efekt interwencji państwa wykonywanej przy użyciu tych środków. Cele powinny zawierać opis przedmiotu lub stanu rzeczy, które mają być wynikiem realizacji zadania lub podzadania; 
- $\quad$ spójne, tj. zapewniające wzajemną zgodność celów w ramach hierarchii struktury budżetu zadaniowego, w poszczególnych zadaniach i podzadaniach nie powinny powielać się nazwa, treścią oraz kierunkiem interwencji;

- mierzalne, tj. sformułowane tak, aby stopień ich osiagnięcia był możliwy do zmierzenia za pomocą mierników, dla których dane są dostępne na etapie planowania i realizacji budżetu;

- określone w czasie, tj. uwzględniające okres, w którym mają być realizowane. Winny odnosić się do przyszłości w kontekście stanu istniejącego w chwili obecnej, tj. opisywane przez wartość bazową mierników dobranych do tych celów;

- realistyczne, tj. sformułowane tak, aby już w założeniu brać pod uwage ocenę ryzyka ich realizacji, jednakże winny oscylować wokół spodziewanych, pozytywnych wyników wykonania zadania, a nie minimum gwarantującego pewność osiagnięcia celu. Cele powinny zakładać poprawę wyników w obszarze danej polityki, a nie utrwalać jedynie stan obecny w tym zakresie. Postęp nie jest konieczny jedynie w przypadkach, gdy wyniki danej działalności kształtują się na poziomie optymalnym dla możliwości państwa [Rozporzqdzenie Ministra Finansów..., 2014].

Mierniki natomiast powinny:

a) umożliwiać określenie stopnia realizacji celów, tj. mierzyć skuteczność i efektywność realizacji: zadań, podzadań i działań, zgodnie z art. 175 ust. 1 pkt 4 Ustany z. dnia 27 sierpnia 2009 roku o finansach publicznych;

b) być adekwatne do stopnia realizacji postawionych celów oraz skutecznie i efektywnie oddawać rzeczywisty obraz mierzonego obszaru;

c) być spójne z miernikami określonymi na innych poziomach klasyfikacji budżetowej w układzie zadaniowym;

d) być zdefiniowane w sposób umożliwiajacy ciagłość ich pomiaru w wieloletniej perspektywie;

e) mierzyć tylko to, na co wykonawca podzadania lub działania ma wpływ;

f) posiadać wiarygodne i szybko dostępne źródło danych [Rozporząqzenie Ministra Finansów..., 2014].

Dla każdego miernika ustala się wartość docelową i wartość bazową. Przez wartość bazową miernika rozumie się ostatnią, dostępną wartość miernika $(\mathrm{N}-2)$. Za wartość docelową miernika uznaje się wartość, którą zamierza się osiagnąć w danym roku budżetowym (bez uwzględnienia rezerw celowych), na który sporządza się projekt ustawy budżetowej (rok N). W przypadku mierników odnoszących się do nowych zadań publicznych nie określa się wartości bazowej. Nie jest możliwe ustalanie mierników o wartościach opisowych, logicznych oraz ukazujących poziom finansowania lub jego dynamikę.

Istotą budżetu zadaniowego jest wyraźne określenie zadań, które są finansowane ze środków budżetowych. Z kolei, dzięki zastosowaniu mierników istnieje możliwość oceny stopnia realizacji celów, a także efektów uzyskanych w wyniku ponoszonych wydatków budżetowych. Budżet zadaniowy jest planem wydatków budżetowych, sporządzanym w układzie: funkcji, zadań, podzadań i działań wraz ze wskazaniem celów, 
które planuje osiagnąc się za sprawą realizacji zadań oraz mierników określających stopień realizacji celów. W Polsce układ zadaniowy funkcjonuje równolegle z tradycyjnym układem wydatków. Jednostki sektora finansów publicznych są zobowiązane do prowadzenia ewidencji wydatków budżetowych w układzie tradycyjnym, tj. według klasyfikacji budżetowej, jak również ewidencjonowania tych samych wydatków w układzie zadaniowym. Budżet zadaniowy, przygotowany zgodnie z obowiązującymi zasadami, może być wykorzystany jako narzędzie poprawy efektywności i skuteczności zarządzania jednostka.

\section{Funkcjonowanie budżetu zadaniowego w Podlaskim Urzędzie Wojewódzkim}

Przedmiotem badań empirycznych jest mechanizm funkcjonowania budżetu zadaniowego w Podlaskim Urzędzie Wojewódzkim w odniesieniu do działania: „Pomoc państwa w zakresie dożywiania oraz pomoc żywnościowa dla najuboższych" (13.1.2.6.). Decyzję o wyborze tylko jednego działania do analizy podjęto $\mathrm{z}$ uwagi na fakt, że skupienie się na węższym obszarze badań umożliwia bardziej przejrzysta prezentację danych liczbowych, przy czym, według najlepszej wiedzy autorek, podobne wnioski można sformułować na podstawie analizy pozostałych działań realizowanych w urzędzie ${ }^{1}$. Pierwsze prace nad wprowadzeniem budżetu zadaniowego w badanej jednostce rozpoczęto w 2006 roku, jednakże dopiero 2016 rok pozwolił na ukazanie dojrzałej wersji mechanizmu jego funkcjonowania, ze względu na wcześniejszy brak stabilności w układzie zadaniowym wydatków. W ramach tego działania monitoruje się środki przekazywane z budżetu państwa (za pośrednictwem budżetu wojewodów) jednostkom samorządu terytorialnego na realizowanie zadań w ramach programu podjętego Uchwała nr 221 Rady Ministrów z. dnia 10 grudnia 2013 roku w sprawie ustanowienia wieloletniego programu wspierania finansowego gmin w zakresie došzwiania „Pomoc państwa w zakeresie dosiywiania" na lata 2014-2020 [Uchwała nr 221 Rady Ministrón..., 2015].

Analizę budżetu zadaniowego w Podlaskim Urzędzie Wojewódzkim (w ramach wybranego działania) warto rozpocząć od przedstawienia korzyści związanych z jego stosowaniem. W wyniku budżetowania zadaniowego, ustalany $\mathrm{w}$ ramach corocznych prac nad projektem budżetu, podział środków finansowych jest bardziej przejrzysty i zrozumiały, ponieważ środki przypisuje się jasnym celom i konkretnym zadaniom, które będą realizowane w danym roku budżetowym. W budżecie zadaniowym wieloletniemu programowi wspierania gmin w zakresie dożywiania „Pomoc państwa w zakresie dożywiania” zostało zadedykowane konkretne działanie: 13.1.2.6. „Pomoc państwa w zakresie dożywiania oraz pomoc żywnościowa dla najuboższych”. Oprócz kwoty przeznaczonej dla gmin na realizację tego programu, w działaniu tym również ujęto wynagrodzenia pracowników urzędu wojewódzkiego zajmujących się obsługą tego programu. W układzie zadaniowym wyraźnie została określona kwota na realizację

${ }^{1}$ Warto zwrócić uwage na dużą liczbę działań realizowanych w badanej jednostce. Przykładowo, budżet wojewody podlaskiego w układzie zadaniowym, według ustawy budżetowej na 2016 rok, został sklasyfikowany w: 18 funkcjach, 42 zadaniach, 75 podzadaniach i 129 działaniach. 
całego zadania, a na każdym szczeblu klasyfikacji zadaniowej jasno sprecyzowany cel i miernik służący jego realizacji (tabela 1.).

W przypadku podziału środków, w układzie tradycyjnej klasyfikacji budżetowej nie ukazuje się faktycznych kosztów realizacji zadania. W układzie tradycyjnym środki na realizację wieloletniego programu wspierania gmin w zakresie dożywiania „Pomoc państwa w zakresie dożywiania” są sklasyfikowane w dziale 852 - „Pomoc społeczna”, rozdział 85295 - „Pozostała działalność” (tabela 2.). W ustawie budżetowej na 2016 rok w klasyfikacji tej były także ujęte środki na realizację Programu „Rodzina 500 Plus" oraz dotacje przeznaczone na finansowe wspieranie programów w obszarze pomocy społecznej, realizowanych przez uprawnione podmioty. Ze względu na to, że w budżecie tradycyjnym środki finansowe, uwzględnione w tej klasyfikacji, sa prezentowane $\mathrm{w}$ jednej kwocie, $\mathrm{z}$ danych przedstawianych w ustawie budżetowej czy sprawozdawczości budżetowej nie można pozyskać informacji dotyczących powyższych zadań. W zwiazku z powyższym, budżet tradycyjny jest mniej zrozumiały i przejrzysty [Ustawa budìetowa na rok 2016..., 2016].

Kolejną z możliwości, jaką daje budżet zadaniowy, jest lepsza ocena efektywności wydatkowanych środków. Można wyliczyć efekty i porównać je z kosztami, co jest podstawą do podejmowania racjonalnych decyzji na temat sposobu dalszej realizacji zadań. W budżecie zadaniowym określa się mierniki, które służą pomiarowi stopnia realizacji celu. Miernikiem dla działania 13.2.1.6. jest liczba osób korzystających z dożywiania w ramach programu. Dzięki temu, ogólnie dostępna jest informacja, że na przykład docelowo z tej formy pomocy w województwie podlaskim w 2016 roku skorzystało 68411 osób (tabela 1.). Na podstawie miernika można określić, czy został zrealizowany cel (zapenmienie pomocy w zakeresie dosigniania osobom i rodżnom znajdujacym sie $w$ trudnej sytuacji syciowej), na który były przeznaczone środki z budżetu państwa. Ponadto, istnieje możliwość porównania kosztu jednostkowego, zarówno w poszczególnych województwach, jak i w kolejnych latach. Co więcej, budżet zadaniowy daje możliwość elastycznego dostosowania trybu i terminów pomiaru miernika w zależności od dostępności danych (pomiar może być: miesięczny, kwartalny, półroczny, roczny, inny). Jednocześnie zawsze jest wskazana komórka organizacyjna (jednostka, wydział, biuro, zespół) odpowiedzialna za realizację danego miernika. Wzrasta więc świadomość urzędników w zakresie ich odpowiedzialności za wydatkowanie środków publicznych na realizację zadań.

W Podlaskim Urzędzie Wojewódzkim stopień realizacji celu, jakim jest zapewnienie pomocy w zakresie dosyniania osobom i rodzinom znajdujacym sie w trudnej sytuacji syyciowej jest mierzony kwartalnie. Dane do pomiaru pochodza ze sprawozdań kwartalnych, jakie gminy są zobowiązane składać do wojewody. W budżecie zadaniowym wykorzystuje się dostępne dane, nie ma konieczności dodatkowego zbierania informacji, by monitorować osiagnięcie miernika. Urząd został zobligowany do realizacji konkretnych zadan, na które otrzymał konkretne środki i dzięki budżetowi zadaniowemu może być rozliczany z wyników. Jeśli dany cel został sformułowany wraz z miernikami jego realizacji, to wówczas istnieje możliwość oceny stopnia jego realizacji. 


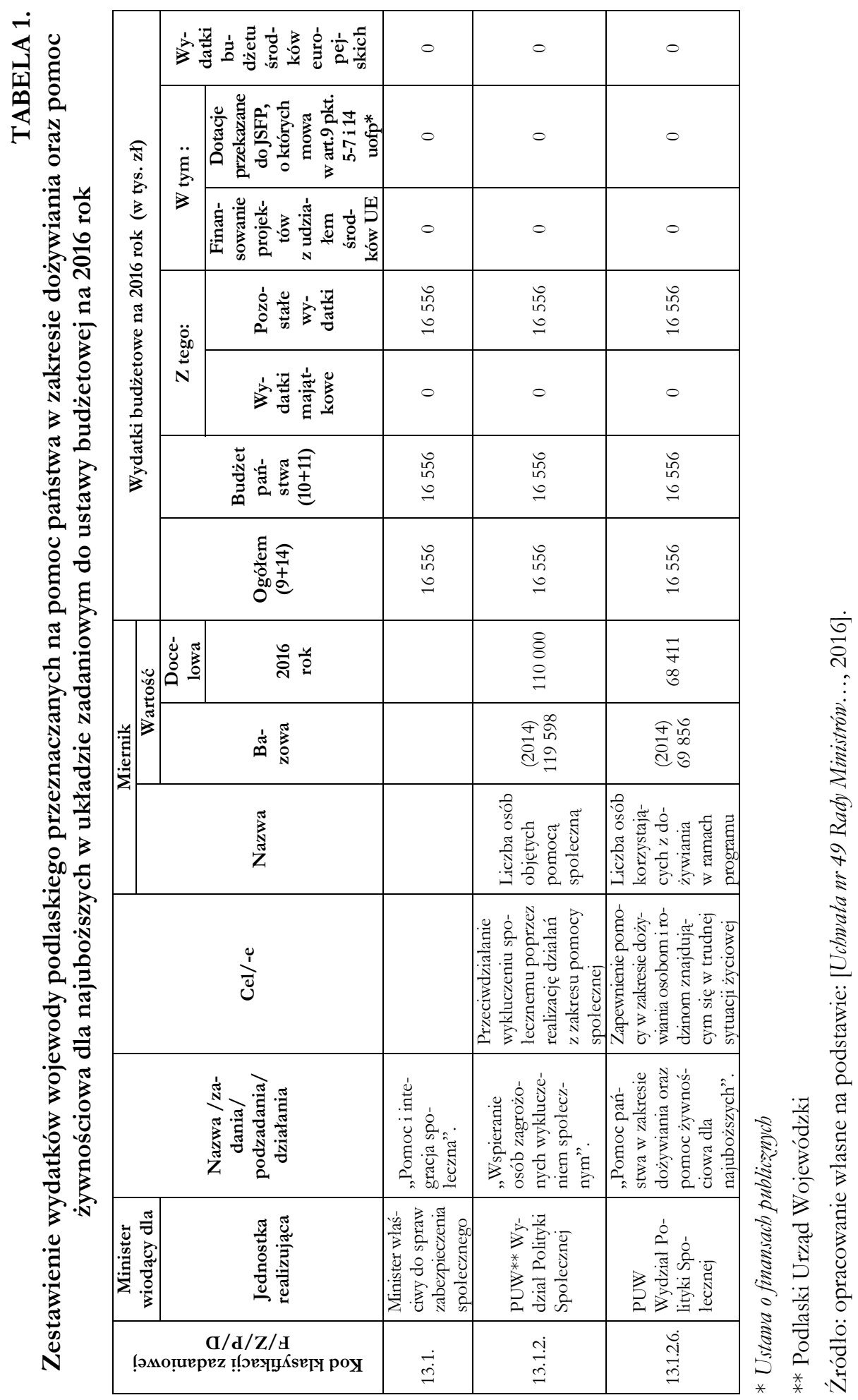


TABELA 2.

Zestawienie wydatków wojewody podlaskiego na pomoc w zakresie dożywiania, w układzie tradycyjnym, według ustawy budżetowej na 2016 rok

\begin{tabular}{|c|c|c|c|}
\hline \multirow[t]{3}{*}{ Dział } & \multirow[t]{3}{*}{ Rozdział } & \multicolumn{2}{|c|}{ Wydatki (w tys. zł) } \\
\hline & & \multirow{2}{*}{$\begin{array}{l}\text { Kwota } \\
\text { łącznie }\end{array}$} & W tym: \\
\hline & & & $\begin{array}{l}\text { Pomoc państwa w zak- } \\
\text { resie dożywiania }\end{array}$ \\
\hline $\begin{array}{c}852 \text { - „Pomoc } \\
\text { społeczna” }\end{array}$ & $\begin{array}{l}\text { 85295 - „Pozostała działal- } \\
\text { ność” } \\
\text { W Ustawie budżetowej na } 2016 \text { rok, } \\
\text { w rozdziale 85295 - „Pozostała } \\
\text { działalność” ujęto poniższe za- } \\
\text { dania. } \\
\text { 1) Dotacja przeznaczona na rea- } \\
\text { lizację zadania własnego gmin } \\
\text { w ramach programu „Pomoc } \\
\text { państwa w zakresie dożywia- } \\
\text { nia” - dotacje przekazywane } \\
\text { przez wojewodę podlaskiego } \\
\text { jednostkom samorządu tery- } \\
\text { torialnego. } \\
\text { 2) Program „Rodzina 500+” - } \\
\text { dotacje przekazywane przez } \\
\text { wojewodę podlaskiego jed- } \\
\text { nostkom samorządu teryto- } \\
\text { rialnego. } \\
\text { 3) Dotacja przeznaczona na fi- } \\
\text { nansowe wspieranie progra- } \\
\text { mów w obszarze pomocy spo- } \\
\text { łecznej, realizowanych przez } \\
\text { uprawnione podmioty - do- } \\
\text { tacje przekazywane przez wo- } \\
\text { jewodę podlaskiego innym jed- } \\
\text { nostkom, np. stowarzyszeniom. }\end{array}$ & 507956 & $16513^{*}$ \\
\hline $\begin{array}{c}750- \\
\text { „Administracja } \\
\text { publiczna” }\end{array}$ & $\begin{array}{l}75011 \text { - urzędy wojewódzkie, } \\
\text { par. } 4020 \text { - wynagrodzenia oso- } \\
\text { bowe członków korpusu służby } \\
\text { cywilnej (wynagrodzenia pracow- } \\
\text { ników Podlaskiego Urzędu Woje- } \\
\text { wódzkiego). }\end{array}$ & 19123 & $43^{*}$ \\
\hline
\end{tabular}

* Informacja dostępna na podstawie ewidencji wydatków w układzie zadaniowym.

Źródło: opracowanie własne na podstawie: [Ustawa budżetowa na rok 2016..., 2016]. 


\section{Ograniczenia w zakresie możliwości wykorzystania budżetu zadaniowego w Podlaskim Urzędzie Wojewódzkim}

Obok korzyści płynących ze stosowania budżetu zadaniowego, dysponenci środków budżetowych muszą jednocześnie zmierzyć się z pojawiającymi się trudnościami w tym zakresie. Do istotnych problemów należy brak stabilizacji struktury układu zadaniowego - przez co nie ma możliwości porównywania danych finansowych oraz wartości mierników w perspektywie dłuższej niż rok, także brakuje możliwości porównywania sposobów alokacji środków. Nie dotyczy to tylko przyjmowania różnych kluczy podziału wydatków pośrednich, ale również sposobu przypisywania wydatków bezpośrednich. Wobec tego, budżet zadaniowy traci jedną ze swoich podstawowych funkcjonalności - charakter prezentacyjny jakości i skuteczności działania urzędu. Minister Finansów, widząc potrzebę ujednolicenia budżetu zadaniowego, na 2016 rok skatalogował cele i mierniki do siedmiu funkcji. W pozostałych jedenastu funkcjach dysponenci środków mają możliwość dowolnego stosowania celów i mierników.

Brak stabilizacji struktury układu zadaniowego jest widoczny przy porównaniu zestawienia wydatków na realizację programu „Pomoc państwa w zakresie dożywiania” w roku 2015 i 2016. Nie ma w tym zakresie trwałości zarówno numeracji pozycji klasyfikacyjnych, jak i nazewnictwa. W 2015 roku było to podzadanie 13.1.1. i działanie 13.1.1.8., natomiast w 2016 roku było to podzadanie 13.1.2. i działanie 13.1.2.6. Mając inną klasyfikację zadaniowa, trudno jest dokonać analizy porównawczej wyników realizacji zadania $\mathrm{w}$ kolejnych latach. Jednocześnie nazwa działania z roku na rok zmienia się. W 2015 roku analizowane wydatki były ujęte w działaniu: Program wieloletni „Pomoc państwa w zakresie dożywiania”, zaś w 2016 roku: „Pomoc państwa w zakresie dożywiania oraz pomoc żywnościowa dla najuboższych” (por. tabele: 1., 3. i 4.).

Kolejną przeszkodą we wdrażaniu budżetu zadaniowego jest brak jednolitych wytycznych, przepisów nakazujących stosowanie takich samych mierników i sposobów alokacji środków. Precyzyjne uregulowania w tym obszarze umożliwiłyby ujednolicenie sposobu przyporządkowywania przez jednostki w różnych województwach czynności i spraw oraz związanych z nimi wydatków do poszczególnych działań układu zadaniowego, a co za tym idzie, zarazem porównywanie kosztów realizacji zadań w poszczególnych województwach. W praktyce nie ma wspólpracy właściwych ministerstw odpowiedzialnych za realizację danego zadania z wojewodami (na których jest nałożony obowiązek stosowania budżetu zadaniowego). Poza tym, jednostki samorzadu terytorialnego nie maja obowiązku stosowania budżetu zadaniowego, a to one najczęściej mają bezpośredni wpływ na wykonanie miernika. W trakcie realizacji budżetu informacje $\mathrm{w}$ zakresie budżetu zadaniowego sa gromadzone w urzędzie wojewódzkim i w służbach zespolonych, podległych wojewodzie. Jedynie na etapie planowania budżetu oraz w zakresie sprawozdawczości (półrocznej) informacje są przekazywane do Ministerstwa Finansów. Budżet tradycyjny obejmuje swoim zasięgiem wszystkie jednostki, w tym samorządy, tym samym zamyka krag podmiotów korzystających ze środków publicznych, a budżet zadaniowy jest stosowany jedynie w urzędzie wojewódzkim, więc nie obejmuje wszystkich podmiotów zainteresowanych (tabela 5.). 


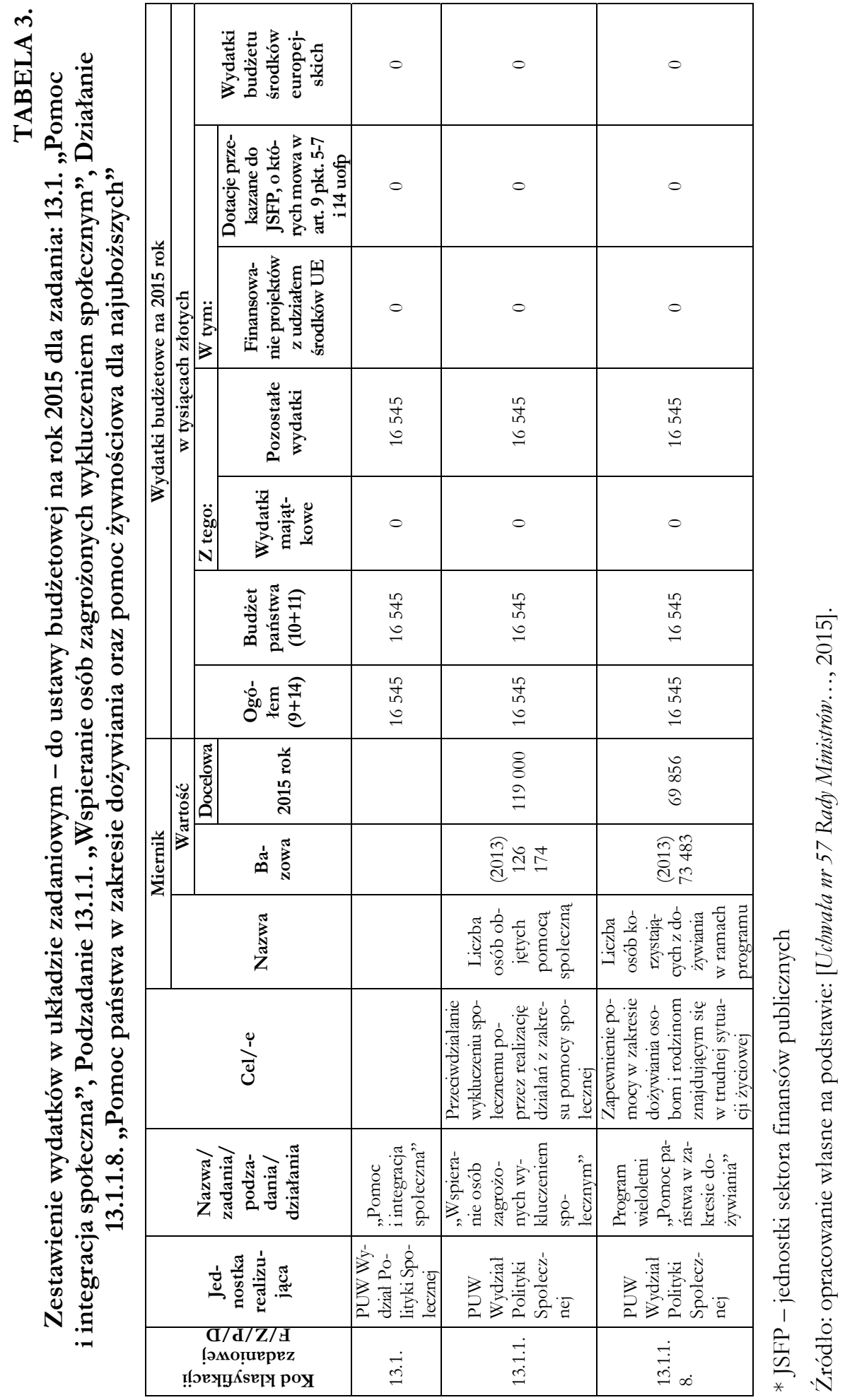


TABELA 4.

Zestawienie wydatków wojewody podlaskiego na pomoc w zakresie dożywiania, w układzie tradycyjnym, według ustawy budżetowej na 2015 rok

\begin{tabular}{|c|c|c|c|}
\hline \multirow[t]{3}{*}{ Dział } & \multirow[t]{3}{*}{ Rozdział } & \multicolumn{2}{|c|}{ Wydatki (w tys. zł) } \\
\hline & & Ogółem & W tym: \\
\hline & & & Dożywianie \\
\hline $\begin{array}{c}852 \text { - „Pomoc } \\
\text { społeczna” }\end{array}$ & $\begin{array}{l}\mathbf{8 5 2 9 5} \text { - „Pozostała działalność” } \\
\text { Obejmuje poniższe zadania. } \\
\text { 1) Dotacja przeznaczona na realizację zada- } \\
\text { nia własnego gmin w ramach programu } \\
\text { „Pomoc państwa w zakresie dożywiania” } \\
\text { - dotacje przekazywane przez wojewodę } \\
\text { podlaskiego JST*. } \\
\text { 2) Dotacja przeznaczona na finansowe wspie- } \\
\text { ranie programów w obszarze pomocy spo- } \\
\text { łecznej, realizowanych przez uprawnione } \\
\text { podmioty - dotacje przekazywane przez } \\
\text { wojewodę podlaskiego innym jednostkom, } \\
\text { np. stowarzyszeniom. }\end{array}$ & 16613 & $16513^{* *}$ \\
\hline $\begin{array}{l}750-, \text { Admi- } \\
\text { nistracja pu- } \\
\text { bliczna” }\end{array}$ & $\begin{array}{l}75011 \text { - urzędy wojewódzkie, par. } 4020 \text { - } \\
\text { wynagrodzenia osobowe członków korpusu } \\
\text { służby cywilnej (wynagrodzenia pracowni- } \\
\text { ków Podlaskiego Urzędu Wojewódzkiego). }\end{array}$ & 17841 & $32 *$ \\
\hline
\end{tabular}

* Są to jednostki samorządu terytorialnego.

** Informacja dostępna na podstawie ewidencji wydatków w układzie zadaniowym.

Źródło: opracowanie własne na podstawie: [Ustawa budžetowa na rok 2016 ₹ dnia 15 stycznia 2015 roku, Dz. U. 2015, poz. 153].

Do istotnych mankamentów należy także opracowywanie budżetu zadaniowego na podstawie kwot wynikających z budżetu tradycyjnego, przez co umniejsza on swoje znaczenie na etapie tworzenia (planowania) budżetu. Oparcie polityki finansowej wyłącznie na budżecie zadaniowym prowadziłoby do bardziej racjonalnego podziału środków finansowych. W tradycyjnym budżecie podział środków ustala się co roku, głównie na podstawie struktury z lat ubiegłych (tzw. planowanie wskaźnikowe). Potrzebne jest planowanie wieloletnie, $z$ rozpisaniem realizacji zadań na poszczególne lata, przy zapewnieniu odpowiednich środków finansowych, z możliwością śledzenia postępów realizacji celu. 
TABELA 5. Występowanie o środki budżetu państwa pochodzące $z$ rezerw celowych na zadanie realizowane przez JST w zakresie dożywiania, w trakcie roku budżetowego

\begin{tabular}{|l|l|c|c|}
\hline \multicolumn{1}{|c|}{ Jednostka } & \multicolumn{1}{|c|}{ Wyszczególnienie } & \multicolumn{2}{|c|}{$\begin{array}{c}\text { Występowanie klasyfika- } \\
\text { cji }\end{array}$} \\
\cline { 3 - 4 } & & $\begin{array}{c}\text { W układzie } \\
\text { tradycyjnym: } \\
\mathbf{8 5 2 , ~ 8 5 2 9 5 ,} \\
\mathbf{2 0 3 0}\end{array}$ & $\begin{array}{c}\text { W układzie } \\
\text { zadanio- } \\
\text { wym } \\
\mathbf{1 3 . 1 . 2 . 6 .}\end{array}$ \\
\hline $\begin{array}{l}\text { Ministerstwo } \\
\text { Rodziny Pracy } \\
\text { i Polityki Spo- } \\
\text { łecznej } \\
\text { (MRPiPS) }\end{array}$ & $\begin{array}{l}\text { Pismo z MRPiPS informujące o środkach z Rezernyy } \\
\text { celowej na program „Dożywianie na rok budżetowy” }\end{array}$ & & \\
\hline $\begin{array}{l}\text { Podlaski Urząd } \\
\text { Wojewódzki }\end{array}$ & $\begin{array}{l}\text { Wniosek Wydziału Polityki Społecznej (WPS) do } \\
\text { Wydziału Finansów Budżetu o wystąienie do Mi- } \\
\text { nistra Finansów o środki }\end{array}$ & $\mathrm{x}$ & $\mathrm{x}$ \\
\hline $\begin{array}{l}\text { Podlaski Urząd } \\
\text { Wojewódzki }\end{array}$ & $\begin{array}{l}\text { Wystapienie wojewody podlaskiego do Ministerstwa } \\
\text { Finansów o środki }\end{array}$ & $\mathrm{x}$ & \\
\hline $\begin{array}{l}\text { Ministerstwo } \\
\text { Finansów }\end{array}$ & $\begin{array}{l}\text { Decyzja Ministerstwa Finansów zwiększająca plan } \\
\text { wydatków }\end{array}$ & $\mathrm{x}$ & \\
\hline $\begin{array}{l}\text { Podlaski Urząd } \\
\text { Wojewódzki }\end{array}$ & $\begin{array}{l}\text { Decyzja wojewody podlaskiego sporządzona przez Wy- } \\
\text { dział Finansów i Budżetu na podstawie decyzji Mi- } \\
\text { nisterstwa Finansów, zwiększająca środki dla WPS }\end{array}$ & $\mathrm{x}$ & $\mathrm{x}$ \\
\hline $\begin{array}{l}\text { Podlaski Urząd } \\
\text { Wojewódzki }\end{array}$ & $\begin{array}{l}\text { Podział środków na poszczególne JST zaakceptowa- } \\
\text { ny przez wojewodę podlaskiego, sporządzony przez } \\
\text { WPS }\end{array}$ & $\mathrm{x}$ & $\mathrm{x}$ \\
\hline $\begin{array}{l}\text { Podlaski Urząd } \\
\text { Wojewódzki }\end{array}$ & $\begin{array}{l}\text { Wydział Polityki Społecznej przekazuje zaakcepto- } \\
\text { wany podział do Wydziału Finansów i Budżetu }\end{array}$ & $\mathrm{x}$ & \\
\hline $\begin{array}{l}\text { Podlaski Urząd } \\
\text { Wojewódzki }\end{array}$ & $\begin{array}{l}\text { Decyzja zwiększająca dotację gminom - na podsta- } \\
\text { wie zaakceptowanego podziału sporządza Wydział } \\
\text { Finansów i Budżetu - do wiadomości przekazuje WPS }\end{array}$ & $\mathrm{x}$ & \\
\hline $\begin{array}{l}\text { Podlaski Urząd } \\
\text { Wojewódzki }\end{array}$ & $\begin{array}{l}\text { Dyspozycja o uruchomienie środków dla JST - WPS } \\
\text { przekazuje do Wydziału Finansów i Budżetu }\end{array}$ & $\mathrm{x}$ & \\
\hline $\begin{array}{l}\text { Podlaski Urząd } \\
\text { Wojewódzki }\end{array}$ & Wydział Finansów i Budżetu przekazuje środki JST & $\mathrm{x}$ & \\
\hline
\end{tabular}

x* - Przy przekazywaniu środków dla JST, klasyfikacja zadaniowa jest podawana wyłącznie na potrzeby sprawozdawcze PUW.

Źródło: opracowanie własne na podstawie faktycznego obiegu dokumentów.

Kolejnym problemem jest brak wypracowanej metodyki oraz narzędzi umożliwiających realizację przepisów art. 175 Ustawy o finansach publicżyych, dotyczących sprawowania części budżetowych nadzoru i kontroli przez dysponentów, m.in. w zakresie efektywności i skuteczności realizacji planu w układzie zadaniowym na podstawie mierników stopnia realizacji celów. Dodatkowo, istnieje opór pracowników merytorycznie zaangażowanych w realizację budżetu w układzie zadaniowym (często są to osoby, 
które nie mają styczności z budżetem tradycyjnym) w związku z dużym obciążeniem praca, przy jednoczesnym braku widocznych efektów stosowania budżetu zadaniowego.

TABELA 6.

\section{Porównanie klasyfikacji bieżących wydatków pozapłacowych Podlaskiego Urzędu Wojewódzkiego w ujęciu tradycyjnym i zadaniowym}

\begin{tabular}{|c|c|}
\hline $\begin{array}{l}\text { Budżet tradycyjny - dział 750, rozdział } \\
\text { 75011, paragraf }\end{array}$ & Budżet zadaniowy - działanie \\
\hline $\begin{array}{l}\text { Paragraf } 302 \text { „Wydatki osobowe niezaliczo- } \\
\text { ne do wynagrodzeñ" }\end{array}$ & \multirow{10}{*}{$\begin{array}{l}\text { 22.1.1.1. „Koordynacja działalności oraz } \\
\text { obsługa administracyjna i techniczna” }\end{array}$} \\
\hline $\begin{array}{l}\text { Paragraf } 400 \text { „Grupa wydatków bieżących } \\
\text { jednostki” }\end{array}$ & \\
\hline Paragraf 427 ,Zakup usług remontowych” & \\
\hline Paragraf 441 „Podróże służbowe krajowe” & \\
\hline $\begin{array}{l}\text { Paragraf } 442 \text { „Podróże służbowe zagra- } \\
\text { niczne” }\end{array}$ & \\
\hline Paragraf 443 „Różne opłaty i składki” & \\
\hline Paragraf 448 „Podatek od nieruchomości” & \\
\hline $\begin{array}{l}\text { Paragraf } 452 \text { „Opłaty na rzecz budżetów } \\
\text { jednostek samorządu terytorialnego” }\end{array}$ & \\
\hline $\begin{array}{l}\text { Paragraf } 455 \text { „Szkolenia członków korpusu } \\
\text { służby cywilnej” }\end{array}$ & \\
\hline $\begin{array}{l}\text { Paragraf } 470 \text { „Szkolenia pracowników nie- } \\
\text { będacych członkami korpusu służby cywil- } \\
\text { nej” }\end{array}$ & \\
\hline
\end{tabular}

Źródło: opracowanie własne na podstawie: [Plan finansony Podlaskiego Urz̨edu Wojewódækiegego na 2016 rok, 2016].

Ponadto, w urzędach wojewódzkich większość wydatków, związanych z bieżącym utrzymaniem urzędu, jest ujmowanych w jednej funkcji - 22., zadaniu - 22.1., podzadaniu - 22.1.1., działaniu - 22.1.1.1. „Koordynacja działalności oraz obsługa administracyjna i techniczna". Stanowi to bardzo poważne ograniczenie przy zastosowaniu budżetu zadaniowego jako narzędzia wspomagającego efektywne zarządzanie. Kadra zarządzająca faktycznie ma wpływ na wydatkowanie środków na wynagrodzenia oraz pozapłacowe wydatki rzeczowe. W związku z tym, że większość wydatków pozapłacowych jest ujmowanych w funkcji 22., traci się możliwość wykorzystania narzędzi, jakie daje budżet zadaniowy, tj. celów i mierników do efektywnego zarządzania jednostka. W tym przypadku podział środków w układzie tradycyjnym daje większą możliwość prezentacji rodzaju wydatków niż układ zadaniowy (tabela 6.). 


\section{Ocena wykorzystania budżetu zadaniowego jako narzędzia poprawy jakości rządzenia}

Powołując się na koncepcję identyfikującą sześć wymiarów dobrego rządzenia, można dokonać analizy i oceny obszarów poprawy jakości rządzenia przy wykorzystaniu budżetu zadaniowego. Biorąc pod uwagę zarówno zalety, jak i wady funkcjonowania budżetu zadaniowego w Podlaskim Urzędzie Wojewódzkim, można sformułować ogólny wniosek związany z możliwościami efektywniejszego zarządzania jednostką [por. Postuła, 2015]. Podstawowym argumentem przemawiającym za tym jest fakt, że całokształt działalności urzędu został ujęty w katalogu funkcji/zadań/podzadań/ działań. Daje to możliwość przejrzystego przedstawienia zadań realizowanych w urzędzie oraz poniesionych na nie wydatków. W ten sposób realizuje się zasadę przejrzystości - prezentowanie budżetu i realizowanych zadań w układzie budżetu zadaniowego pozwala na pełną dostępność do informacji publicznej. Oprócz kosztów realizacji zadania, również powszechnie jest dostępna informacja dotycząca celów zaplanowanych do osiagnięcia i mierników oceny. Dzięki budżetowi zadaniowemu, istnieje łatwy sposób badania efektywności i skuteczności osiaganych celów. Budżet zadaniowy umożliwia porównanie kosztów jednostkowych realizacji zadania (między województwami, jednostkami samorządu terytorialnego czy jednostkami budżetowymi), zarazem pozwala na ocenę racjonalności prowadzonej gospodarki finansowej. Niestety, z uwagi na brak ogólnie dostępnych informacji w zakresie rzeczowych efektów realizowanych zadań, nie można stwierdzić, że budżet zadaniowy spełnia funkcję decyzyjna.

Odnosząc się do partycypacji i społecznej inkluzji, można uznać, że ten wymiar jakości rządzenia jest także brany pod uwage przez umożliwienie realizacji zadań publicznych jednostkom niższego szczebla. Mimo to budżet państwa jest wciąż określany jako „wskaźnikowy”, więc wpływ ten jest bardzo niewielki. Gdyby budżet zadaniowy był podstawą do przyznania środków budżetowych poszczególnym dysponentom, bez ograniczeń wynikających obecnie np. z Ustany o finansach publičnych, chociażby dotyczących przeniesień wydatków między podziałkami klasyfikacji budżetowej, mieliby oni większy wpływ na realizowane zadania. Jednocześnie budżet zadaniowy stałby się podstawa do stworzenia mechanizmów rozliczania tych dysponentów z wcześniej przyjętych założeń i podjętych decyzji. Jest to jednak warunek do spełnienia w przyszłości. Obecnie zasadniczym narzędziem rozliczalności jest prawidłowe wydatkowanie środków publicznych.

Równocześnie poprawę jakości rządzenia można rozpatrywać przez pryzmat ujęcia pewnych elementów $\mathrm{z}$ zakresu budżetu zadaniowego w takich obszarach, jak kontrola zarządcza. W Podlaskim Urzędzie Wojewódzkim podjęto próbę połączenia tych aspektów dzięki wprowadzeniu procesu zarządzania ryzykiem opartego na celach i zadaniach wyszczególnionych w budżecie zadaniowym. Docelowo zarządzanie ryzykiem i budżet zadaniowy mają tworzyć system spójnych narzędzi kontroli zarządczej. Aktualnie w urzędzie to rozwiązanie jest testowane. Opracowano mechanizm pozwalający na analizę ryzyka w budżecie zadaniowym. Dyrektorzy komórek organizacyjnych przedkładają informację o zagrożeniach realizacji celów w budżecie, w układzie zadanio- 
wym. Dokonują identyfikacji i analizy ryzyka, w szczególności: analizują zidentyfikowane ryzyko w celu określenia prawdopodobieństwa wystapienia tego ryzyka oraz jego skutków, proponują sposób postępowania w odniesieniu do poszczególnych ryzyk, przedstawiają działania zaradcze podjęte wobec zidentyfikowanych ryzyk w zakresie posiadanych kompetencji. Koordynator do spraw budżetu zadaniowego weryfikuje przedłożone materiały i sporządza informację zbiorcza, wskazując na ryzyka, które w sposób istotny zagrażają realizacji celów w jednostce. Opracowaną informację przekazuje się do dyrektora generalnego oraz do komórki organizacyjnej zajmującej się kontrolą zarządczą, aby porównać ją z wynikami kwartalnych raportów z ryzyka (por. tabela 7.).

TABELA 7.

Analiza ryzyka w budżecie zadaniowym w zakresie działania 13.1.2.6. (wraz z monitoringiem)

\begin{tabular}{|c|c|c|c|c|c|}
\hline $\begin{array}{l}\text { Wy- } \\
\text { dział } \\
\text { reali- } \\
\text { zujący } \\
\text { działa- } \\
\text { nie }\end{array}$ & $\begin{array}{l}\text { Kod klasy- } \\
\text { fikacji za- } \\
\text { daniowej, } \\
\text { nazwa } \\
\text { działania }\end{array}$ & Cel & Miernik & $\begin{array}{c}\text { Ocena } \\
\text { osią- } \\
\text { gnięcia } \\
\text { mier- } \\
\text { nika } \\
\text { (TAK/ } \\
\text { NIE) }\end{array}$ & Opis ryzyka \\
\hline 1 & 2 & 3 & 4 & 5 & 6 \\
\hline $\begin{array}{l}\text { WPS } \\
\text { Od- } \\
\text { dział } \\
\text { Plano- } \\
\text { wania } \\
\text { i Analiz }\end{array}$ & $\begin{array}{c}\text { 13.1.2.6. } \\
\text { „Pomoc } \\
\text { państwa } \\
\text { w zakresie } \\
\text { dożywiania } \\
\text { oraz pomoc } \\
\text { żywnościo- } \\
\text { wa dla naj- } \\
\text { uboższych”. }\end{array}$ & $\begin{array}{l}\text { Zapewnienie } \\
\text { pomocy w zak- } \\
\text { resie dożywia- } \\
\text { nia osobom } \\
\text { i rodzinom } \\
\text { znajdującym } \\
\text { się w trudnej } \\
\text { sytuacji ży- } \\
\text { ciowej. }\end{array}$ & $\begin{array}{c}\text { Liczba } \\
\text { osób ko- } \\
\text { rzystają- } \\
\text { cych z do- } \\
\text { żywiania } \\
\text { w ramach } \\
\text { progra- } \\
\text { mu. }\end{array}$ & TAK & $\begin{array}{l}\text { Ryzyko zewnętrzne zwiazane ze zmiana } \\
\text { sytuacji gospodarczej, w tym zwłaszcza } \\
\text { na rynku pracy może mieć wpływ na } \\
\text { zmianę liczby osób korzystajacych } \\
\text { z programu. Zmiany w przepisach. } \\
\text { Brak zainteresowania, rezygnacja up- } \\
\text { rawnionych osób z korzystania z róż- } \\
\text { nych form pomocy. Nasilenie czyn- } \\
\text { ności proceduralnych, co może wią- } \\
\text { zać się z wycofywaniem się osób. }\end{array}$ \\
\hline
\end{tabular}

\begin{tabular}{|c|c|c|c|c|c|}
\hline $\begin{array}{c}\text { Ocena } \\
\text { wpływu } \\
\text { ryzyka na } \\
\text { działanie }\end{array}$ & $\begin{array}{c}\text { Prawdopo- } \\
\text { dobieństwo } \\
\text { wystapienia } \\
\text { ryzyka }\end{array}$ & $\begin{array}{c}\text { Poziom } \\
\text { istotno- } \\
\text { ści ry- } \\
\text { zyka }\end{array}$ & $\begin{array}{c}\text { Metody przeciwdziałania } \\
\text { ryzyku }\end{array}$ & $\begin{array}{c}\text { Efekt zasto- } \\
\text { sowanych } \\
\text { metod } \\
\text { (I kwartał) }\end{array}$ & $\begin{array}{c}\text { Efekt zasto- } \\
\text { sowanych } \\
\text { metod } \\
\text { (II kwartał) }\end{array}$ \\
\hline $\mathbf{7}$ & $\mathbf{8}$ & $\mathbf{9}$ & $\mathbf{1 0}$ & $\mathbf{1 1}$ & $\mathbf{1 3}$ \\
\hline Niskie (1) & Niskie(1) & $\begin{array}{c}\text { Nie- } \\
\text { znaczne } \\
(1)\end{array}$ & $\begin{array}{c}\text { 1) Bieżaca analiza wydatko- } \\
\text { wanych środków i analiza } \\
\text { sprawozdań. } \\
\text { wydatkowanych śnodków. } \\
\text { 3) Monitorowanie sytuacji } \\
\text { na rynku pracy. } \\
\text { 4) Analiza kwartalnych spra- } \\
\text { wozdań „Pomoc państwa } \\
\text { w zakresie dożywiania”. }\end{array}$ & $\begin{array}{c}\text { Ryzyko nie } \\
\text { wystapiło. }\end{array}$ & $\begin{array}{c}\text { Ryzyko nie } \\
\text { wystapiło. }\end{array}$ \\
\hline
\end{tabular}

Źródło: opracowanie własne na podstawie: [Analiza ryzylka w budżecie zadanionym Podlaskiego Uržedu Wojewódzkiego na 2016 rok]. 
Dzięki takiemu rozwiązaniu, pracownicy komórek merytorycznych dostrzegli spójność budżetu zadaniowego z kontrolą zarządcza, w tym z zarządzaniem ryzykiem. Podjęte działania przede wszystkim doprowadziły do wyeliminowania różnic w określaniu ryzyka oraz definiowaniu mierników. Docelowo dokumenty, które dotyczą budżetu zadaniowego i zarządzania ryzykiem, mają stanowić jeden spójny zbiór.

\section{Podsumowanie}

Wyniki przeprowadzonych badań skłaniają do kilku refleksji. Po pierwsze, budżet zadaniowy, funkcjonujący w obecnej formule w Polsce na poziomie władzy rządowej, w województwie ma wyłącznie charakter prezentacyjny. Wbrew ciagłym pracom nad jego udoskonalaniem, nadal nie odgrywa on swojej głównej roli, tj. narzędzia służącego do racjonalnego wydatkowania środków publicznych. Stanowi on jedynie uzupełnienie budżetu tradycyjnego. Pomimo wielu niedoskonałości, dostarcza obywatelom czytelną informację o rozdysponowywaniu środków z budżetu państwa. Można go również wykorzystać jako narzędzie wspomagające efektywne zarządzanie. Stąd, w sensie poprawy jakości rządzenia, spełnia on kryterium demokratycznego państwa prawnego i kryterium przejrzystości. Kolejne wymiary dobrego rządzenia, takie jak: rozliczalność, skuteczność i efektywność oraz partycypacja społeczna i inkluzja, będa mogły być realizowane dzięki budżetowi zadaniowemu wtedy, gdy zostanie on wprowadzony jako obligatoryjne narzędzie we wszystkich jednostkach sektora publicznego, to natomiast spowoduje większą dbałość o realizację określonych w nim celów.

\section{Współudział autorów w powstaniu artykułów}

dr Aneta Kargol-Wasiluk - opracowanie koncepcji badań oraz części teoretycznej, współudział w przeprowadzeniu badań i opracowaniu wyników - 50\%

mgr Ewa Wojewódko - zebranie danych, analiza podstaw prawnych, współudział w przeprowadzeniu badań i opracowaniu wyników - 50\%

\section{Literatura}

Analiza ryzyka w budżecie zadanionym Podlaskiego Uræ̨edu Wojewódžkiego na 2016 rok, dokument wewnętrzny Podlaskiego Urzędu Wojewódzkiego.

Cheema G.S., 2005, Building democratic institutions: governance reform in developing countries, Kumarian Press Inc., New York.

Conceptualizing and Researching Governance in Public and Non-profit Organizations, 2013, F. Monteduro, A. Hinna, L. Gnan (eds.), Studies in Public and Non-Profit Governance, vol. 1, Emerald Group Publishing Limited United Kingdom - North America - Japan - India - Malaysia - China. 
Fukuyama F., 2013, What is governance, "Governance: An International Journal of Policy, Administration, and Institutions", vol. 26, no. 3.

Fukuyama F., 2014, Good Government, Bad Government, "Political Development", vol. 10, no. 2.

Grosse T. G., 2009, Dylematy dobrego rzqdzenia (good governance). Wnioski dla Polski, „Studia Polityczne”, nr 23.

Hardt L., de Jong M., 2011, Budżet zadaniowy jako narzedzie poprawy jakości rzqdzenia $w$ Polsce, Ernst\&Young, Warszawa.

Hill C. J., Lynn L. E. Jr, 2004, Governance and Public Management, an Introduction, "Journal of Public Analysis and Management", vol. 23, no. 1.

Innovations in public governance, 2011, P. Valkama, S.J. Bailey, A. V. Anttiroiko (eds.), IOS Press, Amsterdam.

Jakość rzqdzenia w Polsce. Jak ja badać, monitorować i poprawiać?, 2013, J. Wilkin (red.) Wydawnictwo Naukowe Scholar, Warszawa.

Jessop B., 2007, Promowanie „dobrego rzqdzenia” i ukrywanie jego słabości: refleksja nad politycznymi paradygmatami i politycznymi narracjami w sferze rzqdzenia, „Zarządzanie Publiczne", nr 2.

Kargol-Wasiluk A., 2011, Public governance jako wyzwanie dla współczesnego panstwa, „Prace Naukowe Uniwersytetu Ekonomicznego we Wrocławiu. Polityka Ekonomiczna”, nr 166.

Orientations on Participatory Development and Good Governance, 1993, OECD, DAC, Paris.

Performance Budgeting in OECD Countries, 2007, OECD.

Peteres B.G., 2012, Is Governance for Evrybody? The Use and Abuse of Governance, [in:] Governance: Is It for Everyone?, A.M. Bissessar (ed.), Nova Science Publishers Inc., New York.

Plan finansowy Podlaskiego Urz̨du Wojewódzkiego na 2016 rok, 2016, Podlaski Urząd Wojewódzki.

Postuła M., 2015, Instrumenty zarzqdzania finansami publicznymi, Wydawnictwo Naukowe Wydziału Zarządzania Uniwersytetu Warszawskiego, Warszawa.

Postuła M., Perczyński P., 2008, Budżet zadaniowy w administracji publicznej, Ministerstwo Finansów, Warszawa.

Public governance, 2015, S. Mazur (ed.), Wydawnictwo Naukowe Scholar, Warszawa.

Rotberg R. I., 2004, Strengthening Governance: Ranking Countries Would Help, "The Washington Quarterly", vol. 28, no. 1.

Rozporzqdzenie Ministra Finansów z. dnia 17 czerwca 2014 r. w sprawie sqczególowego sposobu, trybu i terminów opracowania materiałów do projektu ustany budżetowej na 2015 r., Dz. U. 2014, Nr 0, poz. 825.

Schick A., 2007, Performance Budgeting and Accrual Budgeting: Decision Rules or Analytic Tools?, "OECD Journal on Budgeting", vol. 7, no. 2.

Uchwała nr 221 Rady Ministrów z. dnia 10 grudnia 2013 roku w sprawie ustanowienia wieloletniego programu wspierania finansowego gmin w zakeresie dożyiania „Pomoc państwa w zakeresie dożywiania” na lata 2014-2020, t.j., M.P. 2015, poz. 821.

Uchwata nr 49 Rady Ministrów z dnia 26 kwietnia 2016 roku w sprawie Wieloletniego Planu Finansowego Państwa na lata 2016-2019, M. P. 2016, poz. 454. 
Uchwała nr 57 Rady Ministrów z dnia 28 kwietnia 2015 roku w sprawie Wieloletniego Planu Finansowego Pañstwa na lata 2015-2018, M. P. 2015, poz. 389.

Ustawa budi்etowa na rok. 2007. Uzasadnienie, http://www.mf.gov.pl/ministerstwofinansow/dzialalnosc/finanse-publiczne/budzet-panstwa/ustawy-budzetowe/ archiwum (data wejścia: 20.02.2017).

Ustawa budżetowa na rok 2016 z dnia 15 stycznia 2015 roku, Dz. U. 2015, poz. 153.

Ustawa budżetowa na rok 2016 z dnia 25 lutego 2016 roku, Dz. U. 2016, poz. 278.

Ustawa z dnia 27 sierpnia o finansach publicznych, tekst jednolity, Dz. U. 2013, poz. 885 z późn. zm. 